\title{
Dietary Administration of Common Sage (Salvia officinalis) and Coneflower (Echinacea angustifolia) Extracts Affects Growth, Blood Parameters and Immune Responses of Beluga, Huso huso
}

\author{
Hadiseh Dadras ${ }^{1, *}\left(\mathbb{D}\right.$, Mohammad Reza Hayatbakhsh $^{1}$, Amin Golpour ${ }^{1}$, \\ ${ }^{1}$ Islamic Azad University, Young Researchers and Elite Club, Lahijan BranchLahijan, Iran.
}

\section{Article History}

Received 04 February 2019

Accepted 10 September 2019

First Online 17 September 2019

\section{Corresponding Author}

Tel.: +989113450917

E-mail: fh.dadras@gmail.com

\section{Keywords}

Immunostimulant

Great sturgeon

Growth performance

Herb

Innate immune system

\begin{abstract}
The purpose of the present study was to investigate the effects of Salvia officinalis and Echinacea angustifolia extracts on growth performance, blood parameters and innate immune responses of beluga, Huso huso. Six experimental diets were prepared using S. Officinalis (SAE-30, SAE-60, SAE-120) and E. angustifolia (EAE-30, EAE-60 and EAE120) extracts containing concentrations of 30,60 and $120 \mathrm{ml} / \mathrm{kg}$ feed, respectively. A control diet $(C D)$ was prepared without extracts inclusion. The fish fed the diet containing $120 \mathrm{ml} / \mathrm{kg}$ of $E$. angustifolia extract (EAE-120) showed significant $(P<0.05)$ higher final weight $(885.7 \pm 11.5 \mathrm{~g})$, body weight $(318.5 \pm 8.5 \%)$ and feed efficiency (72.7 \pm 9.1$)$ compared to those of other experimental diets. In addition, SGR (1.8 \pm $0.14)$ and FCR $(2.7 \pm 0.18)$ were significantly improved in fish fed diet containing 30 $\mathrm{ml} / \mathrm{kg}$ of $E$. angustifolia extract (EAE-30) compared to those of other experimental diets. All haematological parameters were influenced by inclusion of Salvia officinalis and Echinacea angustifolia extracts. The serum alanine aminotransferase (ALT) and aspartate aminotransferase (AST) levels were significantly lower in supplemented diet groups compared to the control. The lysozyme activity $(31.6 \pm 3.3 \mu \mathrm{g} / \mathrm{ml}$ ) and alternative complement activity $(130.3 \pm 10.9 \mathrm{U} / \mathrm{ml})$ in the serum of fish fed diet containing $120 \mathrm{ml} / \mathrm{kg}$ of $E$. angustifolia extract (EAE-120) showed significant difference compared to the other treatments $(P<0.05)$. These results revealed remarkable beneficial effects of $E$. angustifolia extract on innate immune and growth performance of the beluga.
\end{abstract}

\section{Introduction}

In aquaculture, feeding is one of the most important factors influencing growth, feed utilization and tissue composition of fish in intensive culture (Nya \& Austin, 2009; Talpur, Ikhwanuddin, Abdullah, \& Bolong, 2013). The afore-mentioned chemicals have not been recently recommended in commercial aquaculture due to their residual effects on muscle of cultured species (Sambhu, 1996; Citarasu, Babu, Sekar, \& Marian, 2002; Sagdic \& Ozcan, 2003). In the recent years, the concern about bacterial resistance to antibiotics in livestock industry has led to minimizing application of such compounds. Other adverse impacts of antibiotics are development of resistant bacteria, presence of antibiotic residues in meat and destruction of the bacterial population in the cultivated aquatic environment (Marques et al., 2005; Shalaby, Khattab, \& Abdel Rahman, 2006). Thus, several studies have focused on natural products such as plants or their extracts as possible alternative to antibiotics (Sivaram, Babu, Immanuel, Murugadass, Citarasu, \& Marian, 2004; Acar, Parrino, Kesbiç \& Paro, 2018; Baba, Acar, Yılmaz, Ergün, Saoca, Abbate, Yılmaz, \& Fazio, 2018). Plants and their extracts are known to play a significant role in preventing diseases via potential properties of antimicrobial and antioxidant activities (Buchanan, Hott, Cutlip, Rack, Asamer, \& Moritz, 2008; Gabor, Sara, \& Barbu, 2010). These bioactive components exert their beneficial effects by manipulating the intestinal microflora and improving digestibility. The natural plant origin products such as vegetables, herbs, spices, edible 
plants, and their extracts are not explained as traditional feed additives for animal nutrition. However, various parts of these plants (fruit, leaves, oil) have been traditionally utilized in folk medicine since ancient times. These plant based feed additives act as growth promoters, immunostimulants or antimicrobial agents, representing the proper alternative to antibiotics and other chemotherapeutics with no detrimental impact on environment (Galindo-Villegas \& Hosokawa, 2004). Since, herbal products enhance the activity of nonspecific defense system (Dorucu, Colak, Ispir, Altinterim, \& Celayir, 2009; Citarasu, 2010; Wang, Sun, Liu, \& Xue, 2016), their effects on different fish species has become routine practice. Various types of substances are known to act as immunostimulants, but only a few are suitable to be used in fish farming. The immunostimulants have been categorized as natural (biological) and synthetic (chemical) substances that stimulate and enhance lysozyme activity, lymphocyte activity, antibody production and protection against pathogens (Citarasu, 2010; Van Hai, 2015). The common sage, Salvia officinalis is a plant endemic in Mediterranean countries with great medical importance. It has strong antioxidant activity due to the presence of excellent antimicrobial activity and hypoglycemic properties (Kamatou, Van Vuuren, Van Heerden, Seaman, \& Viljoen, 2007; Eidi \& Eidi, 2009). The main antioxidant and antimutagenic effects of $S$. officinalis are related to the presence of activecompounds such as: carnosic acid carnosol, rosmarinic acid and camphor (Cuvelier, Berset, \& Richard, 1994; Miliauskas, van Beek, Venskutonis, Linssen, \& de Waard, 2004). In addition, extract of Coneflower, Echinacea purpurea has been used traditionally for the treatment of various types of infections and wounds. Studies have shown the effect of E. purpurea as immune-modulator, comprising stimulation of certain immune functions such as phagocytic activity of macrophages and suppression of the proinflammatory responses of epithelial cells to viruses and bacteria (Vimalanathan, Kang, Amiguet, Livesey, Arnason, \& Hudson., 2005; Hudson, 2009). Thus, the aim of the present study was to investigate the effect of different levels of $S$. officinalis and $E$. angustifolia extracts as feed additives on growth performance, haematological parameters and nonspecific immune system in beluga

\section{Materials and Methods}

\section{Preparation of Experimental Diets}

The commercially available ethanolic extracts of $S$. officinalis and E. angustifolia (Zardband Pharmaceutical Company Ltd., Tehran, Iran) were purchased and prepared as a dietary additive. Six experimental diets were prepared based on S. officinalis (SAE-30, SAE-60, SAE-120) and E. angustifolia (EAE-30, EAE-60, EAE-120). $A$ control diet (CD) was served without addition of extracts in diet. The designated concentrations of both herbs $(30,60$ and $120 \mathrm{ml}$ per $1 \mathrm{~kg}$ feed) were incorporated into the commercial diet (Skretting, 1.1 $\mathrm{mm}$ diameter, Puerto Montt, Chile) by first mixing with vegetable oil as carrier and then top-spraying. The control diet was also sprayed with vegetable oil (contains no extract). The proximate composition of main ingredients of commercial feed are measured as $57 \%, 9.5 \%, 0.9 \%$ and $0.4 \%$ for protein, ash, fat and fiber.The experimental diets were dried at room temperature for $2 \mathrm{~h}$ and then stored in sealed polythene bags at $4^{\circ} \mathrm{C}$ until further use.

\section{Experimental Set up}

The juveniles of great sturgeon $(268.3 \pm 0.41 \mathrm{~g})$ were supplied from the Dafchah Sturgeon Fish Propagation and Rearing Centre (Rasht, Iran). Fish were stocked in acclimation for two weeks prior to beginning the experiment; during this period they were fed formulated diet. After the acclimation period, fish were stocked in rearing tanks (400 L) at density of 15 specimens per tank within an indoor flow-through system supplied with pumped-ashore filtered natural freshwater $(100 \mathrm{~L} / \mathrm{h}$. ) under constant 12:12 h (light/dark) schedule. The fish were hand-fed the experimental diets until apparent satiation twice daily (09:00 and 17:00 h) for 6 weeks. Water temperature, dissolved oxygen and $\mathrm{pH}$ were maintained at $15^{\circ} \mathrm{C}, 7.3$ and 8.0, respectively. Continuous aeration was provided to each tank through an air stone connected to a central air compressor.

\section{Evaluation of the Growth Performance}

Growth performance, feed utilization and survival rate were assessed according to average final weight gain, specific growth rate (SGR) and feed conversion ratio (FCR), based on the following formulae:

$$
\begin{aligned}
& \text { Weight gain }(\%)=100-\left(\mathrm{W}_{2}-\mathrm{W}_{1}\right) / \mathrm{W} 1 ; \\
& \text { Specific growth rate }(\mathrm{SGR}, \% / \text { day })=100-\left(\mathrm{Ln} \mathrm{W}_{2}-\mathrm{Ln}\right. \\
& \left.\qquad \mathrm{W}_{1}\right) / \mathrm{T} ; \\
& \text { Feed conversion ratio }(\mathrm{FCR})=\text { feed intake }(\mathrm{g}) / \text { weight } \\
& \text { gain }(\mathrm{g}) ; \\
& \text { Survival rate }(\%)=100-(\mathrm{Nf} / \mathrm{Ni}) ; \\
& \text { Condition factor }(\mathrm{CF})=(\text { body weight }(\mathrm{g}) /(\text { standard } \\
& \text { length }))^{3} \times 100
\end{aligned}
$$

Where $\mathrm{W}_{1}, \mathrm{~W}_{2}, \mathrm{~T}, \mathrm{Ni}$ and $\mathrm{Nf}$ are initial weight (g), final weight (g), number of days in the feeding period, initial and final number of fish, respectively.

FE: feed efficiency $=100 \times($ FBW-IBW $) /$ TF where the TF indicated the total amount of feed given. 


\section{Blood Analysis}

After 24 hours of the last experimental feeding, four fish from each replicate were sedated (200 mg MS $222 /$ of water), blood was collected from the caudal vein either with heparinized or non-heparinized syringes. Heparinized blood was transferred into heparinized tubes and kept on ice for analysis of whole blood parameter within 2 hours. The tubes contain nonheparinized blood (4 fish / tank; 12 fish / treatment) was allowed to clot at room temperature for $30 \mathrm{~min}$ and the serum separated by centrifugation ( $3000 \mathrm{~g}$ for $10 \mathrm{~min}$ ) at room temperature. Then, the serum was separated and stored at $-70^{\circ} \mathrm{C}$ for later analysis. To measure hemoglobin $(\mathrm{Hb})$ concentration, fresh blood was used according to the cyanmethemoglobin method (Jain, 1986). Red blood cells (RBC) and white blood cells (WBC) were counted using a Neubauer hemocytometer and hematocrit $(\mathrm{Ht})$ was measured by routine microhematocrit technique. The smears obtained from heparinized samples were air-dried, fixed in $96 \%$ ethanol for $30 \mathrm{~min}$, stained with Giemsa, and examined by light microscopy to determine differential leukocyte counts (neutrophils, lymphocytes, monocytes and eosinophils). The concentration of serum glucose, cholesterol, total protein and albumin (Alb) were measured by spectrophotometer at $546 \mathrm{~nm}$ (Jenway, 685-SC - UV/VIS, UK) using commercial kits (Pars Azmun, Tehran, Iran). Globulin content was calculated by subtracting albumin content from serum total protein content. Activities of ALT and AST were determined colorimetrically using kits from Pars Azmun Diagnostics (Karaj, Iran).

\section{Immunological Parameters}

The standard procedure suggested by Kumar et al. (2009) was followed for determination of serum lysozyme activity. A suspension of $150 \mathrm{ml}$ lyophilized Micrococcus lysodeikticus (Sigma M-3770), with 0.2 $\mathrm{mg} / \mathrm{ml}$ as substrate in $1 \mathrm{M}$ sodium acetate buffer adjusted to $\mathrm{pH} 5.5$, was added to previously dispensed test serum (15 $\mathrm{ml}$ from each fish) in 96-well U-bottom microliter plate, and initial optical density (OD) was immediately measured at $450 \mathrm{~nm}$. Final OD was assessed after $1 \mathrm{~h}$ incubation at $24^{\circ} \mathrm{C}$. A standard curve was prepared using lyophilized hen egg white lysozyme (HEWL, Sigma, USA). Serum lysozyme values were expressed as $\mathrm{mg} / \mathrm{ml}$.

\section{Serum Immunoglobulin (Ig) and Alternative Complement Activity $\left(\mathrm{ACH}_{50}\right)$ Assay}

Total immunoglobulin levels of blood plasma samples were measured by adding $50 \mu$ blood plasma and equal amount of $12.0 \%$ solution of polyethylene glycol (Sigma) to each well of a 96-well microtiter plate. Samples were incubated for two hours at room temperature, and then the plates were centrifuged
( $5000 \mathrm{~g}$ at $4{ }^{\circ} \mathrm{C}$ ) for $15 \mathrm{~min}$. The supernatant was diluted 30 times with $0.85 \% \mathrm{NaCl}$ and total protein levels were determined according to Bradford method. Samples were measured in triplicates. These values were subtracted from the total protein concentrations, and the results of immunoglobulin-concentrations were expressed as $\mathrm{mg} / \mathrm{ml}$. Also, the alternative complement activity $\left(\mathrm{ACH}_{50}\right)$ of samples was determined using sheep red blood cells (SRBC) as described by Yano (1992).

\section{Statistical Analysis}

Prior to analysis, homogeneity of variances and normality of the data were checked using Levene Kolmogorov-Smirnov test, respectively. Then, data with normal distribution were analyzed by one-way analysis of variance (ANOVA). Duncan test was applied to compare the significant differences among the treatments $(P<0.05)$. The nonparametric statistics using the Kruskal-Wallis test followed by the Mann-Whitney U-test were performed for comparison of non-normally distributed data. All analysis were conducted using SPSS version 18 (SPSS Inc., Chicago, IL, USA). Differences were considered significant at $\mathrm{P}<0.05$ for all analyses. Data were expressed as mean \pm SD.

\section{Results}

The FBW and FE of fish were significantly $(P<0.05)$ affected by the dietary treatments in the rearing period compared to the control (Figure 1). Feed conversion ratio, SGR and CF revealed significant differences among the dietary treatments (Figure 2). The changes in haematological indices are given in Figure 3 and 4 . Significant differences were observed in WBC, $\mathrm{Ht}$ and $\mathrm{Hb}$ in the dietary treatments $(P<0.05)$, but, there were no significant differences $(P>0.05)$ in $R B C$ levels among the dietary treatments. Also, the resutls showed significant differences in $\mathrm{MCV}, \mathrm{MCH}$ and $\mathrm{MCHC}$ contents among the dietary treatments. Among leucocyte counts, only lymphocyte showed significant differences after 6 weeks feeding (Figure 5). Significant differences were observed in serum biochemical constituents among the dietary groups. There was significant difference in glucose level among dietary treatments and the highest were observed in the control and SAE- 60 groups (Table $1)$. Moreover, significant changes were observed in serum total protein, albumin and globulin concentrations among the dietary treatments (Table 1). The effects of S. officinalis and E. angustifolia extracts on serum non-specific immune parameters of $H$. huso are shown in Table 2. Serum ALT and AST levels were higher in the control group than other dietary treatments (Table 2). The serum lysozyme activity and Ig levels showed significant differences among the dietary groups. The highest level of lysozyme was observed in EAE-30 and EAE-120 compared to the other dietary groups (Table 2). While, Ig level was significantly higher 


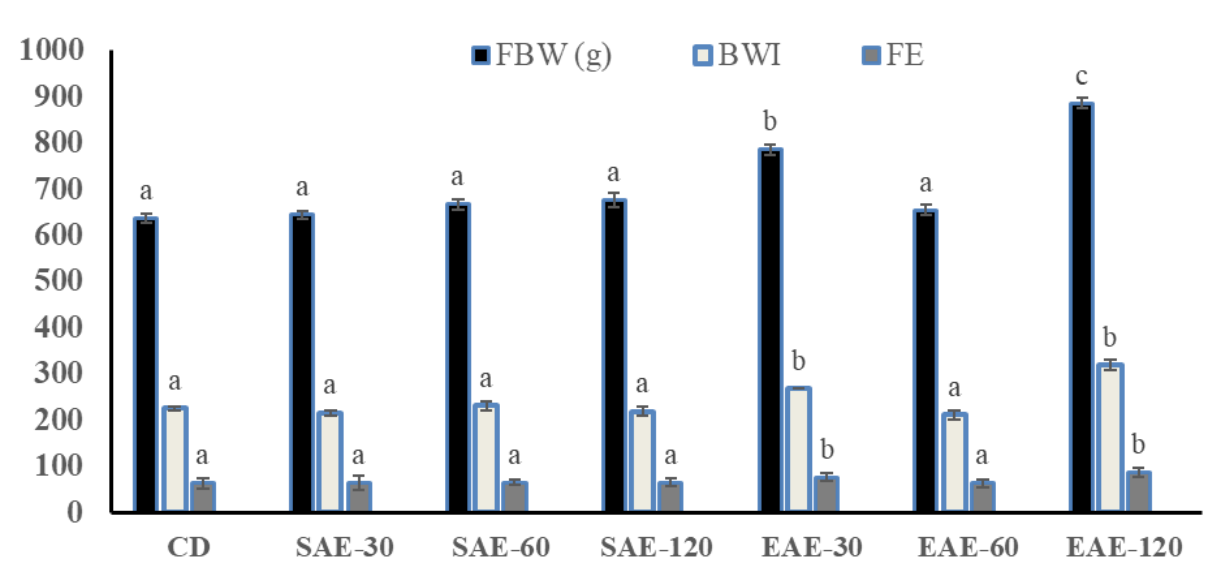

Figure 1. Mean \pm SD of FBW, BWI and FE of the Huso huso fed diets inclusion of Salvia officinalis and Echinacea angustifolia extracts. Different superscript shows significant difference at $P<0.05$.

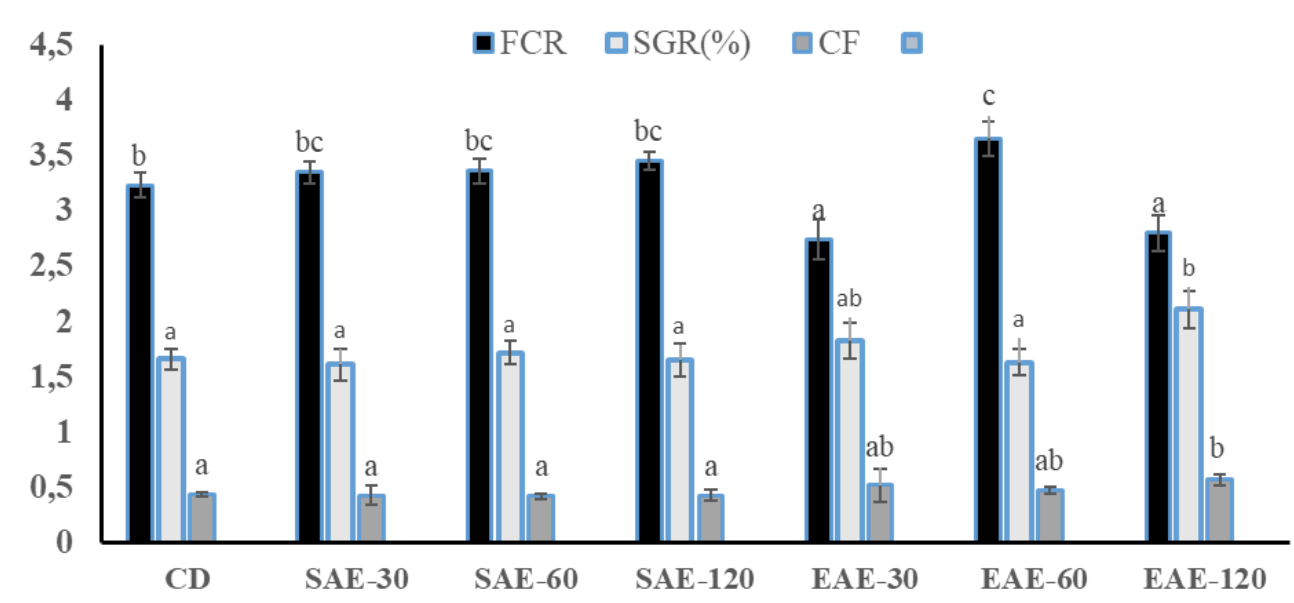

Figure 2. Mean \pm SD of FCR, SGR and CF of the Huso huso fed diets inclusion of Salvia officinalis and Echinacea angustifolia extracts. Different superscript shows significant difference at $\mathrm{P}<0.05$.

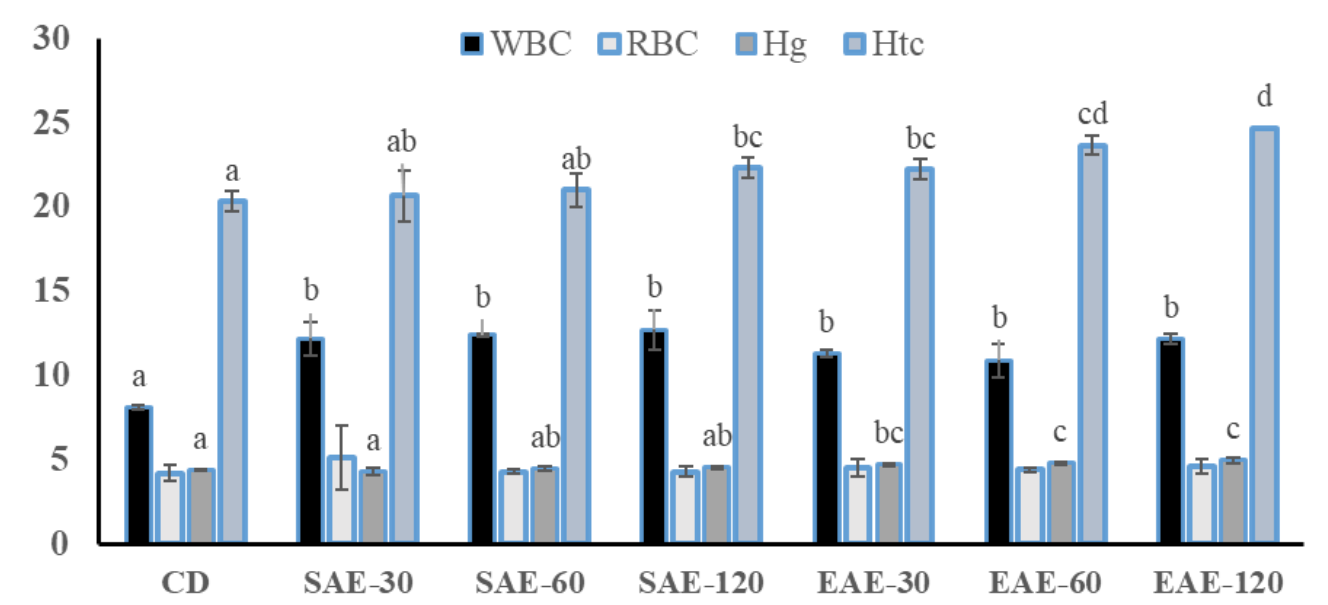

Figure 3. Mean \pm SD of some haematological parameters (WBC, RBC, Hg and Htc) in Huso huso fed diets inclusion of Salvia officinalis and Echinacea angustifolia extracts. Different superscript shows significant difference at $\mathrm{P}<0.05$. 


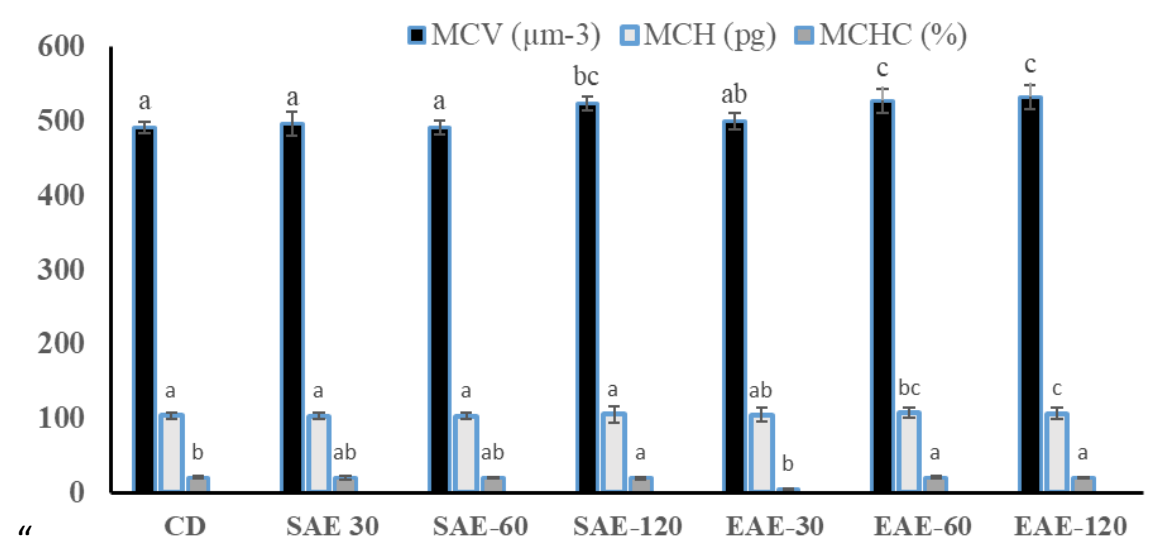

Figure 4. mean $\pm \mathrm{SD}$ of $\mathrm{MCV}, \mathrm{MCH}$ and $\mathrm{MCHC}$ in Huso huso fed diets inclusion of Salvia officinalis and Echinacea angustifolia extracts. Different superscript shows significant difference at $\mathrm{P}<0.05$.

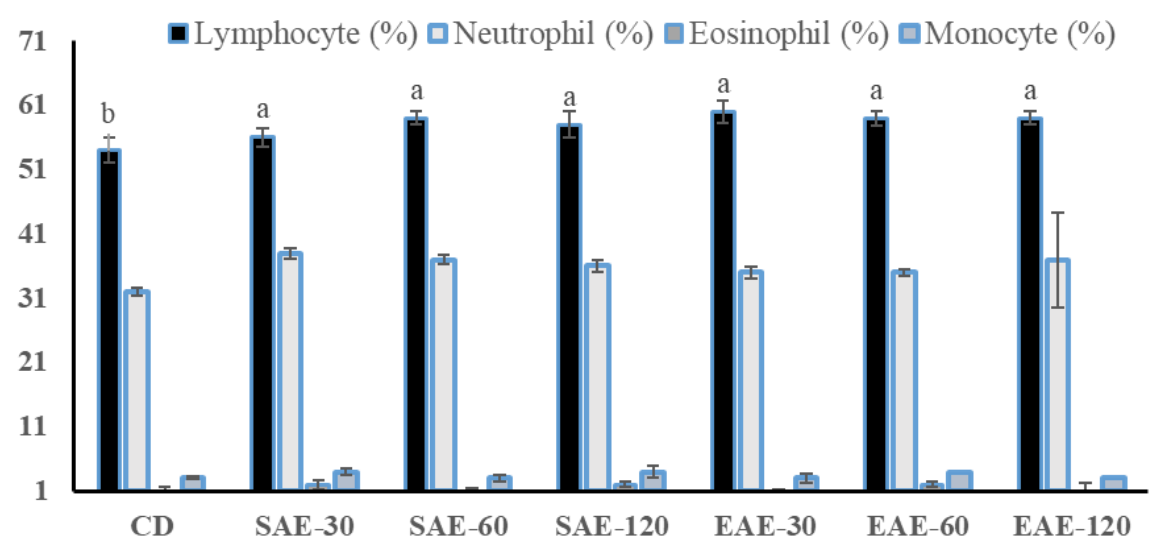

Figure 5. Mean \pm SD of leucocyte counts in Huso huso fed diets inclusion of Salvia officinalis and Echinacea angustifolia extracts. Different superscript shows significant difference at $\mathrm{P}<0.05$.

Table 1. Biochemical parameters of Huso huso following a 60 day diet supplemented with Salvia officinalis and Echinacea angustifolia extracts

\begin{tabular}{lccccc}
\hline Treatments & Glucose $\left(\mathrm{g} \mathrm{dL}^{-1}\right)$ & Total protein $\left(\mathrm{g} \mathrm{dL}^{-1}\right)$ & Calcium $\left(\mathrm{g} \mathrm{dL}^{-1}\right)$ & Globulin $\left(\mathrm{g} \mathrm{dL}^{-1}\right)$ & Albumin $\left(\mathrm{g} \mathrm{dL}^{-1}\right)$ \\
\hline CD & $35 \pm 2.6^{\mathrm{c}}$ & $1.80 \pm 0.10^{\mathrm{a}}$ & $8.1 \pm 0.3$ & $0.92 \pm 0.09^{\mathrm{ab}}$ & $0.88 \pm 0.02^{\mathrm{a}}$ \\
SAE-30 & $27 \pm 2.4^{\mathrm{ab}}$ & $1.83 \pm 0.06^{\mathrm{a}}$ & $7.9 \pm 0.1$ & $0.94 \pm 0.04^{\mathrm{ab}}$ & $0.91 \pm 0.01^{\mathrm{ab}}$ \\
SAE-60 & $35 \pm 3^{\mathrm{c}}$ & $2 \pm 0.05^{\mathrm{b}}$ & $7.3 \pm 0.06$ & $1.03 \pm 0.02^{\mathrm{b}}$ & $0.96 \pm 0.01^{\mathrm{ab}}$ \\
SAE-120 & $28.6 \pm 1.5^{\mathrm{b}}$ & $2.03 \pm 0.06^{\mathrm{b}}$ & $7.4 \pm 0.04$ & $1 \pm 0.01^{\mathrm{ab}}$ & $1.03 \pm 0.06^{\mathrm{b}}$ \\
EAE-30 & $41 \pm 2^{\mathrm{d}}$ & $1.87 \pm 0.06^{\mathrm{a}}$ & $7.3 \pm 0.15$ & $0.87 \pm 0.03^{\mathrm{a}}$ & $0.97 \pm 0.02^{\mathrm{ab}}$ \\
EAE-60 & $22 \pm 1^{\mathrm{a}}$ & $1.90 \pm 0.10^{\mathrm{ab}}$ & $7.2 \pm 0.06$ & $0.94 \pm 0.06^{\mathrm{ab}}$ & $0.96 \pm 0.04^{\mathrm{ab}}$ \\
EAE-120 & $26 \pm 2^{\mathrm{ab}}$ & $2.07 \pm 0.15^{\mathrm{b}}$ & $7.1 \pm 0.10$ & $1.03 \pm 0.06^{\mathrm{b}}$ & $0.99 \pm 0.09^{\mathrm{ab}}$ \\
\hline
\end{tabular}

Means with different alphabetical characters in the same column are statistically different $(\mathrm{P}<0.05)$.

Table 2. Non-specific immune parameters of Huso huso fed diets containing Salvia officinalis and Echinacea angustifolia extracts

\begin{tabular}{lccccc}
\hline Treatments & AST $\left(\mathrm{UL}^{-1}\right)$ & ALT $\left(\mathrm{UL}^{-1}\right)$ & Lysozyme $\left(\mu \mathrm{g} / \mathrm{ml}^{-1}\right)$ & $\mathrm{Ig}\left(\mathrm{mg} / \mathrm{ml}^{-1}\right)$ & $\mathrm{ACH}{ }_{50}(\mathrm{U} / \mathrm{mL})$ \\
\hline CD & $498.3 \pm 15.5^{\mathrm{e}}$ & $91 \pm 2^{\mathrm{c}}$ & $18.6 \pm 1.5^{\mathrm{a}}$ & $10.8 \pm 0.29^{\mathrm{a}}$ & $121.3 \pm 15.5^{\mathrm{ab}}$ \\
SAE-30 & $430.3 \pm 12.4^{\mathrm{d}}$ & $87.3 \pm 2.5^{\mathrm{c}}$ & $23.6 \pm 3^{\mathrm{ab}}$ & $11.4 \pm 0.25^{\mathrm{abc}}$ & $126 \pm 11.5^{\mathrm{abc}}$ \\
SAE-60 & $415 \pm 7^{\mathrm{cd}}$ & $84.6 \pm 2.2^{\mathrm{bc}}$ & $26.7 \pm 1.3^{\mathrm{bc}}$ & $12.2 \pm 0.10^{\mathrm{abc}}$ & $128.6 \pm 10.5^{\mathrm{bc}}$ \\
SAE-120 & $386.6 \pm 13.6^{\mathrm{bc}}$ & $76 \pm 3^{\mathrm{b}}$ & $28.3 \pm 1.4^{\mathrm{bcd}}$ & $12.8 \pm 0.76^{\mathrm{c}}$ & $134 \pm 12^{\mathrm{c}}$ \\
EAE-30 & $413.1 \pm 14.5^{\mathrm{cd}}$ & $77.3 \pm 5.5^{\mathrm{b}}$ & $34.3 \pm 3.1^{\mathrm{d}}$ & $11.2 \pm 0.55^{\mathrm{ab}}$ & $116.3 \pm 9.5^{\mathrm{a}}$ \\
EAE-60 & $373.1 \pm 125^{\mathrm{ab}}$ & $78 \pm 2^{\mathrm{b}}$ & $26 \pm 4^{\mathrm{bc}}$ & $11.3 \pm 0.85^{\mathrm{ab}}$ & $123.6 \pm 5.4^{\mathrm{ab}}$ \\
EAE-120 & $352.3 \pm 15.3^{\mathrm{a}}$ & $63 \pm 4^{\mathrm{a}}$ & $31.6 \pm 3.3^{\mathrm{cd}}$ & $12.4 \pm 0.40^{\mathrm{bc}}$ & $130.3 \pm 10.9^{\mathrm{bc}}$ \\
\hline
\end{tabular}


in SAE-120 and EAE-120 dietary treatments. The $\mathrm{ACH}_{50}$ activity was higher in SAE-120 and EAE-120 dietary treatments (Table 2).

\section{Discussion}

During the past decade, application of herbal extracts as immunostimulants enhances the innate defense mechanisms of fish during stressful periods such as intensive farming practices, grading, sea transfer, vaccination and reproduction (Galina, Yin, Ardo, \& Jeney, 2009). In line with this, the growthpromoting effect was observed in fish fed diet containing S. officinalis and E. angustifolia extracts with increase of SGR and FCR in the present study. These results agree with the findings of Roohi, Imanpoor, Jafari, and Taghizadeh (2017) and Rufchaei, Hoseinifar, Mirzajani, and Van Doan (2017) who reported that the fenugreek (Trigonella foenum graecum) seed meal and Pontogammarus maeoticus extract as feed additives improved the growth parameters (weight gain, SGR and FCR) in common carp, Cyprinus carpio and Caspian roach, Rutilus caspicus respectively. There is no certain reason about enhancement of growth by inclusion of immunostimulants in fish diet, however it has been attributed to the response of local intestinal inflammatory against pathogens, leadin to weight gain (Dalmo \& Bøgwald, 2008; Sirimanapong et al., 2015). It has been proposed that plant based feed additives can modulate intestine microbiota and digestive process, and cause the improved growth performance of fish (MacLennan, Wilson \& Taylor, 2002).

Evaluation of RBC, Hct, $\mathrm{Hb}$ values, and erythrocyte indices are useful to understand physiological status of the organs (Basusta, 2005). In our study, Htc and $\mathrm{Hb}$ levels for beluga fed supplemented diets showed significant differences compared to the control group. This suggests that herbs can improve the performance of the oxygen transport and promote a better tissue perfusion (Rummer and Brauner, 2015). Leucocyte count, erythrocyte count, hematocrit and hemoglobin are particularly recommended as useful indices in fish culture to monitor the health status of the stock (De Pedro, Guijaroo, Lopez-Patino, Martinez-Alvarez, \& Delgado, 2005; Lin et al., 2011). Several medicinal herbs such as ginger (Zingiber officinale Roscoe), garlic (Allium sativum Linn), curcumin and turmeric (Curcuma longa) have improved haematological parameters of fish during rearing (Dügenci et al., 2003; Nya \& Austin, 2009; Nya \& Austin, 2011; Behera, Swain, Sahoo, Mohapatra, \& Das, 2011; Alambra, Alenton, Gulpeo, Mecenas, \& Miranda, 2012). In this study, extracts-supplemented diet improved the haematological indices (WBC, $\mathrm{Hb}$ and $\mathrm{Ht}$ ) that agreed with findings of Kanani, Nobahar, Kakoolaki, and Jafarian (2014), showing the ginger and garlic feed additives improved haemagtological parameters in juvenile bluga. It has been assumed that the enhancement of hematological parameters in fish fed supplemented diets might be related to increase of cell nuclear contents of transcription factors (Sharma et al., 2010). In the present study, the enhanced haematological indices proposed that active ingredients in S. officinalis and E. angustifolia extracts play stimulatory role on the level of many cells.

Total and differential leukocyte counts play prominent role in non-specific defense activities and their count can be considered as an indicator of the health status of fish (De Pedro et al., 2005). Additionally, they are important indices with pivotal activity in response to bacterial, viral and parasitic challenges (Houston, 1990). In the current study, lymphocyte counts in bluga fed $S$. officinalis and E. angustifolia supplemented diets increased significantly. The proliferation of lymphocytes was observed in bluga fed diets supplemented with ginger, garlic and $2 \%$ safflower, Carthamus tinctorius (Kanani et al., 2014; Dadras, Hayatbakhsh, Shelton, \& Golpour, 2016). Since, concentrations of total protein, albumin and globulin in fish plasma are attributed to a potent innate immune response (Wiegertjes, Stet, Parmentier, \& van Muiswinkel, 1996), the innate immune response can be associated with changes in blood biochemical indices.

In the present study, the total protein, albumin and globulin contents was increased using $S$. officinalis and E. angustifolia supplemented diets, indicating the improvment of immune system. Oral administration of herbal medicines have been commonly served as feed additives to enhance the immune response in intensive aquaculture system (Bagni et al., 2005; Van Hai, 2015). Lysozyme is a major components of the innate immune system that prevents biofilm formation by adherence and colonization of microorganisms (Verlhac, Obach, Gabaudan, Schüep, \& Hole, 1998; Magnadóttir, 2006). The immunomodulation of immune system through oral administration of medicinal plant extracts and their products has been attributed to their function in order to regulate the enhanced bactericidal activities, stimulated natural killer cells, complement, lysozyme activity and antibody responses in fish and shellfish (Harikrishnan, Balasundaram, \& Heo, 2011). The results of the present study showed that diet supplemented with $S$. officinalis and $E$. angustifolia extracts can significantly modulate the innate immune responses of bluga (Table 2). Similar to other immunostimulants, a combination of herbs provides beneficial effects to hosts. A mixture of traditional Chinese herbs such as Astragalus membranaceus and Angelica sinensis in diet of common carp and large yellow croaker, Pseudosciena crocea increased plasma lysozyme activity (Jian \& Wu, 2004). The plasma lysozyme activity in Nile tilapia, Oreochromis niloticus fed diets containing a mixture of Astragalus membranaceus and Lonicerajaponica extracts was significantly enhanced (Ardo' et al., 2008).

In conclusion, the present study showed that administration of $E$. angustifolia extract can stimulate innate immune response and feed intake leading to enhanced growth performance. Therefore, this study suggests that utilized herbs can be used as beneficial 
feed additive to improve growth performance and health status (immune system) of bluga during rearing.

\section{Acknowledgment}

The study was financially supported by Young Researchers and Elite Club, Lahijan Branch, Islamic Azad University, Lahijan, Iran.

\section{References}

Acar, Ü., Parrino, V., Kesbiçc, O. S., Lo Paro, G., Saoca, C., Abbate, F., ... \& Fazio, F. (2018). Effects of different levels of pomegranate seed oil on some blood parameters and disease resistance against Yersinia ruckeri in rainbow trout. Frontiers in physiology, 9, 596. https://doi.org/10.3389/fphys.2018.00596

Alambra, J. R., Alenton R. R. R., Gulpeo P. C. R., Mecenas C. L. \& Miranda A. P. (2012). Immunomodulatory effects of turmeric, Curcuma longa (Magnoliophyta, Zingiberaceae) on Macrobrachium rosenbergii (Crustacea, Palaemonidae) against Vibrio alginolyticus Proteobacteria, Vibrionaceae). International Journal of the Bioflux Society, 5(1), 13-17.

Ardo', L., Yin, G., Xu, P., Varadi, L., Szigeti, G., Jeney, Z. \& Jeney, G. (2008). Chinese herbs (Astragalus membranaceus and Lonicera japonica) and boron enhance the non-specific immune response of Nile tilapia (Oreochromis niloticus) and resistance against Aeromonas hydrophila. Aquaculture, 275 , 26-33. https://doi.org/10.1016/j.aquaculture.2007.12.022

Baba, E., Acar, Ü., Yılmaz, S., Zemheri, F. \& Ergün, S. (2018). Dietary olive leaf (Olea europea L.) extract alters some immune gene expression levels and disease resistance to Yersinia ruckeri infection in rainbow trout Oncorhynchus mykiss. Fish and shellfish immunology, 79, 28-33. DOI: 10.1016/j.fsi.2018.04.063

Bagni, M., Romano, N., Finoia, M.G., Abelli, L., Scapigliati, G., Tiscar, P.G., Sarti, M. \& Marino, G. (2005). Shortand long-term effects of a dietary yeast $\beta$-glucan (Macrogard) and alginic acid (Ergosan) preparation on immune response in sea bass (Dicentrarchus labrax). Fish and Shellfish Immunology, 18(4), 311-325. https://doi.org/10.1016/j.fsi.2004.08.003

Boussetta, T., Raad, H., Lettéron, P., Gougerot-Pocidalo, M. A., Marie, J. C., Driss, F., et al. (2009). Punicic acid a conjugated linolenic acid inhibits TNFa-induced neutrophil hyperactivation and protects from experimental colon inflammation in rats. PLoS One, 4, S6458. doi: 10.1371/journal.pone. 0006458

Behera, T., Swain, P., Sahoo, S. K., Mohapatra, D. \& Das, B. K. (2011). Immunostimulatory effects of curcumin in fish, Labeo rohita $(\mathrm{H})$. Indian Journal of Natural Products and Resources, 2,184-88.

Buchanan, N.P., Hott, J.M., Cutlip, S.E., Rack, A.L., Asamer, A. \& Moritz, J.S. (2008). The effects of a natural antibiotic alternative and a natural growth promoter feed additive on broiler performance and carcass quality. Journal of Applied Poultry Research, 17, 202-210. https://doi.org/10.3382/japr.2007-00038

Citarasu, T. (2010). Herbal biomedicines: a new opportunity for aquaculture industry. Aquaculture International, 18 , 403-414. http://dx.doi.org/10.1007/s10499-009-9253-7
Citarasu, T., Babu, M.M., Sekar, R.J.R. \& Marian, P.M. (2002). Developing Artemia enriched herbal diet for producing quality larvae in Penaeus monodon, Fabricus. Asian Fisheries Science, 15, 21-32.

Cuvelier, M.E., Berset, C. \& Richard, H. (1994). Antioxidant constituents in sage (Salvia officinalis). Journal of Agricultural and Food Chemistry 42 (3), 665-9. 10.1021/jf00039a012

Dadras, H., Hayatbakhsh, M. R., Shelton, W. L. \& Golpour, A. (2016). Effects of dietary administration of Rose hip and Safflower on growth performance, haematological, biochemical parameters and innate immune response of Beluga, Huso huso (Linnaeus, 1758). Fish and shellfish immunology, 59, 109-114. 10.1016/j.fsi.2016.10.033

Dalmo, R.A. \& Bøgwald J. (2008). B-Glucans as conductors of immune symphonies, Fish and shellfish immunology, 25 (4), 384-396. 10.1016/j.fsi.2008.04.008

De Pedro, N., Guijaroo, A.E., Lopez-Patino, M.A., MartinezAlvarez, R. \& Delgado, M.J. (2005). Daily and seasonal variations in haematological and blood biochemical parameters in tench (Tincatinca), Aquaculture Research, $36 \quad(12), \quad 1185-1196$. https://doi.org/10.1111/j.1365-2109.2005.01338.x

Dey, R. K. \& Chandra, S. 1995. Preliminary studies to raise disease resistant seed (fry) of Indian major carp Catla catla (Ham.) through herbal treatment of spawn. Fish Chimes, 14, 23-25.

Dorucu, M., Colak, S.O., Ispir, U., Altinterim, B. \& Celayir, Y. (2009). The effect of black cumin seeds, Nigella sativa, on the immune response of rainbow trout (Oncorhynchus mykiss). Mediterranean Aquaculture Journal, 2, 1-7.10.21608/maj.2009.2667

Dügenci, S.K., Arda, N. \& Candan, A. (2003). Some medicinal plants as immunostimulants for fish.

Ethnopharmacology, $88(1)$, 99-106. https://doi.org/10.1016/S0378-8741(03)00182-X

Eidi, A. \& Eidi, M. (2009). Antidiabetic effects of sage (Salvia officinalis L.) leaves in normal and streptozotocin-induced diabetic rats. Diabetes Metabolism: Clinical Research Review, 3, 40-44. https://doi.org/10.1016/j.dsx.2008.10.007

Gabor, E.F., Sara, A. \& Barbu A. (2010). The effects of some phytoadditives on growth, health and meat quality on different species of fish. Animal Science and Biotechnologies, 43, 61-65.

Galina, J., Yin, G., Ardo, L. \& Jeney, Z. (2009). The use of immunostimulating herbs in fish. An overview of research. Fish Physiology and Biochemistry, 35(4), 669-67. 10.1007/s10695-009-9304-z

Harikrishnan, R., Balasundaram, C. \& Heo, M. S. (2011). Review: Impact of plant products on innate and adaptive immune system of cultured finfish and shellfish. Aquaculture, 317, 1-15. https://doi.org/10.1016/j.aquaculture.2011.03.039

Houston, A. H. (1990). Blood and Circulation. In C. B. Schreck \& P. B. Moyle (Eds.), Methods for Fish Biology (pp. 273334). American Fisheries Society, USA.

Hudson, J.B. (2009). The use of herbal extracts in the control of influenza. Journal of Medicinal Plant Research, 3(13), 1189-1194.

Jain, N.C. (1986). Schalms Veterinary Hematology. 4rd ed. Lea and Febiger, Philadelphia, USA.

Jian, J. \& Wu, Z. (2004). Influences of traditional Chinese medicine on non-specific immunity of Jian carp (Cyprinus 
carpio var. Jian). Fish and shellfish immunology, 16(2), 343, 185-191. 10.1016/S1050-4648(03)00062-7

Kamatou, G.P.P., Van Vuuren, S.F., Van Heerden, F.R., Seaman, T. \& Viljoen, A.M. (2007). Antibacterial and antimycobacterial activities of South African indigenous Salvia species and isolated compounds from $S$. chamelaeagnea. South African Journal of Botany, 73(4), https://doi.org/10.1016/j.sajb.2007.05.001

Kanani, H. G., Nobahar, Z., Kakoolaki, S., \& Jafarian, H. (2014). Effect of ginger-and garlic-supplemented diet on growth performance, some hematological parameters and immune responses in juvenile Huso huso. Fish physiology and biochemistry, 40(2), 481-490. 10.1007/s10695-013-9859-6

Kumar, P., Prasad, Y., Patra, A.K., Ranjan, R., Swarup, D., Patra, R.C. \& Pal, S. (2009). Ascorbic acid, garlic extract and taurine alleviate cadmium-induced oxidative stress in freshwater catfish (Clarias batrachus). Science of the Total Environment, 407 (18), 5024-5030. 10.1016/j.scitotenv.2009.05.030

MacLennan, A. H., Wilson, D. H. \& Taylor, A. W. (2002). The escalating cost and prevalence of alternative medicine. Preventive Medicine, 35, 166-173. Doi: 10.1006/pmed.

Magnadóttir, B. (2006). Innate immunity of fish (overview). Fish and shellfish immunology, 20(2), 137151.https://doi.org/10.1016/j.fsi.2004.09.006

Miliauskas, G., van Beek, T.A., Venskutonis, P.R., Linssen, J.P. \& de Waard, P. (2004). Antioxidative activity of Geranium macrorrhizum. European Food Research andTechnology, 218(3), 253-61. https://doi.org/10.1007/s00217-0030836-7

Marques, A., Dinh,T., loakeimidis, C., Huys, G., Swings, J., Verstraete, W., Dhont, J., Sorgeloos, P. \& Bossier, P. (2005). Effects of bacteria on Artemia franciscana cultured in different gnotobiotic environments. Applied and Environmental Microbioly, 71(8), 4307-4317. DOI: 10.1128/AEM.71.8.4307-4317.2005

Nya, E.J. \& Austin B. (2009). Use of garlic, Allium sativum, to control Aeromonas hydrophila infection in rainbow trout, Oncorhynchus mykiss (Walbaum), Journal of Fish Diseases, 32 (11), 963-970. 10.1111/j.13652761.2009.01100.x

Nya, E.J. \& Austin, B. (2011). Development of immunity in Rainbow trout (Oncorhynchus mykiss, Walbaum) to Aeromonas hydrophila after the dietary application of garlic. Fish and Shellfish Immunology, 30, 845-850. 10.1016/j.fsi.2011.01.008

Roohi, Z., Imanpoor, M. R., Jafari, V. \& Taghizadeh, V. (2017). The use of fenugreek seed meal in fish diets: growth performance, haematological and biochemical parameters, survival and stress resistance of common carp (Cyprinus carpio L.). Aquaculture Research, 48(3), 1209-1215. https://doi.org/10.1111/are.12962

Rufchaei, R., Hoseinifar, S. H., Mirzajani, A. \& Van Doan, H. (2017). Dietary administration of Pontogammarus maeoticus extract affects immune responses, stress resistance, feed intake and growth performance of caspian roach (Rutilus caspicus) fingerlings. Fish and shellfish immunology, 63, 196-200. 10.1016/j.fsi.2017.02.017

Rummer, J. L. \& Brauner, C. J. (2015). Root effect haemoglobins in fish may greatly enhance general oxygen delivery relative to other Vertebrates. PLoS One, 10(10), e0139477. doi: 10.1371/journal.pone.0139477
Sagdic, O. \& Ozcan, M. (2003). Antibacterial activity of Turkish spice hydrosols. Journal offood Control, 14, 141-143. https://doi.org/10.1016/S0956-7135(02)00057-9

Sambhu, C. (1996). Effect of hormones and growth promoters on growth and body composition of pearlsport, Etroplus suratensis and white prawn Penaeus indicus. Ph.D. Thesis. University of Kerala, India. 215 pp.

Sharma, P., Kumar, V., Sinha, A. K., Ranjan, J., Kithsiri, H. M. P. \& Venkateshwarlu, G. (2010). Comparative fatty acid profiles of wild and farmed tropical freshwater fish rohu (Labeo rohita). Fish physiology and biochemistry, 36(3), 411-417. DOI 10.1007/s10695-009-9309-7

Shalaby, A.M., Khattab, Y.A. \& Abdel Rahman, A.M. (2006). Effects of garlic (Allium sativum) and chloramphenicol on growth erformance, physiological parameters and survival of Nile tilapia (Oreochromis niloticus). Journal of Venomous Animals and Toxins, 12, 172- 201. http://dx.doi.org/10.1590/S1678-91992006000200003

Sirimanapong, W., Adams, A., Ooi, E.L., Green, D.M., Nguyen, D.K., Browdy, C.L., Collet, B. \& Thompson, K.D. (2015). The effects of feeding immunostimulant $\beta$-glucan on the immune response of Pangasianodon hypophthalmus. Fish and shellfish immunology, 45(2), 357-366. 10.1016/j.fsi.2015.04.025

Sivaram, V., Babu, M.M., Immanuel, G., Murugadass, S., Citarasu, T. \& Marian, M.P. (2004). Growth and immune response of juvenile greasy groupers (Epinephelus tauvina) fed with herbal antibacterial active principle supplemented diets against Vibrio harveyi infections. Aquaculture, 237, 9-20. https://doi.org/10.1016/j.aquaculture.2004.03.014

Talpur, A.D., Ikhwanuddin, M., Abdullah, M.D.D. \& Bolong, A.M.A. (2013) Indigenous Lactobacillus plantarum as probiotic for larviculture of blue swimming crab, Portunus pelagicus (Linnaeus, 1758): effects on survival, digestive enzyme activities and water quality. Aquaculture, 416, 173-178. https://doi.org/10.1016/j.aquaculture.2013.09.018

Tangestani, R., Alizade dughikolaei, E., Ebrahimi, E. \& Zare, P. (2011). Effect of garlic (Allium sativum) essential oil on haematological parameters of juvenile beluga (Huso huso). Journal of Veterinary Research, 663, 209-214.

Van Hai, N. (2015). The use of medicinal plants as immunostimulants in aquaculture: a review. Aquaculture, 446, 88-96. https://doi.org/10.1016/j.aquaculture.2015.03.014

Verlhac, V., Obach, A., Gabaudan, J., Schüep, W. \& Hole, R. (1998). Immunomodulation by dietary vitamin C and glucan in rainbow trout (Oncorhynchus mykiss). Fish and Shellfish Immunology, 8(6), 409-424. https://doi.org/10.1006/fsim.1998.0148

Vimalanathan, S., Kang, L., Amiguet, V.T., Livesey, J., Arnason, J.T. \& Hudson, J. (2005). Echinacea purpurea aerial parts contain multiple antiviral compounds. Pharmaceutical Biology, 43(9), 740-745. https://doi.org/10.1080/13880200500406354

Wang, W., Sun, J., Liu, C. \& Xue, Z. (2016). Application of immunostimulants in aquaculture: current knowledge and future perspectives. Aquaculture Research. DOI: 10.1111/are.13161

Wiegertjes, G.F., Stet, R.J, Parmentier, H.K. \& van Muiswinkel, W.B. (1996). Immunogenetics of disease resistance in fish; a comparable approach. Developmental and Comparative Immunology, 20,365381. https://doi.org/10.1016/S0145-305X(96)00032-8 